\title{
Current State and Development Prospects of Autonomous Haulage at Surface Mines
}

\author{
Yuri Voronov ${ }^{1 *}$, Artyom Voronov ${ }^{1}$, and Daulet Makhambayev ${ }^{2}$ \\ ${ }^{1}$ T.F. Gorbachev Kuzbass State Technical University, Department of Road Transport, 650000 \\ Kemerovo, 28 Vesennya st., Russian Federation \\ ${ }^{2}$ Kazakh Humanitarian Juridical Innovative University, EKR, Semey, 11Mangilik st., Republic of \\ Kazakstan
}

\begin{abstract}
Autonomous (or unmanned) haulage systems have been used in surface mining for more than 10 years. Most of the equipment at such mines is remotely controlled by electronics, for which they are sometimes called "smart mines". The elimination of the "human factor" from the production process should theoretically increase its safety and productivity, as well as reduce the operating costs of its implementation. However, despite the obvious advantages of this technology, it is not spreading as fast as expected. This suggests that there are a number of problems that limit its development. In this paper, a review and analysis of the experience in the industrial implementation of autonomous haulage in surface mining is carried out in order to identify existing problems and possible directions for their further development. The prerequisites, a brief history and some important results of the introduction of autonomous haulage systems in surface mining, their main types and constituent elements are outlined, as well as the existing problems and expected directions of their development are highlighted.
\end{abstract}

\section{Introduction}

In progress of surface mining of minerals, as a rule, hundreds of people and dozens of heavy loading and transport machines are involved, which must work on a tight schedule, often in difficult weather conditions. Intense and monotonous work leads to fatigue, errors, and, as a result, to accidents. A number of mining operations face a complication of mining conditions: mine deepening, mountaintop mining, the risk of bench collapse and other safety problems, because of which mines may be prohibited from operating. In remote and sparsely populated regions, the delivery of workers, their placement, food, etc., are difficult. In addition, competent professionals often refuse to work in such conditions. Thus, the main problems in surface mining arise from the "human factor".

Elimination of the "human factor" also allows to get rid of unproductive downtime of equipment (during shift changes, lunches, etc.). Trials conducted by Caterpillar have shown that unmanned mining trucks have up to $20 \%$ higher performance than manned trucks. Their use exceeded $90 \%$, since they almost did not stand idle and operated on average 2,5

* Corresponding author: vyue.ap@,kuzstu.ru 
hours longer than ordinary trucks. It is also possible to add or remove trucks, regardless of how many operators are available $[1,2]$.

One of the new and suddenly arisen arguments in favor of eliminating the "human factor" is the COVID-19 pandemic, as a result of which many mining operations around the world have reduced volumes, stopped, or even shut down to prevent the spread of infection.

To solve the problems that arise when operating in adverse conditions, as well as to increase productivity, more and more mining companies are beginning to use automation for controlling mining machines.

\section{The current state of "smart mines"}

Autonomous mining is a general term denoting a change in mining technology in such a way as to exclude the use of human labor at the place of mineral extraction. This includes: 1) mining automation, including automation of the technological process and software for it; 2) the use of autonomous control of equipment [2].

There are four levels of automation of mining equipment. The first, simplest and most cheap level is remote control; it is usually used to control the operation of excavators and bulldozers in dangerous places where there is a risk of landslides, explosions or rock fall. The machine is in the field of view of the operator who uses the remote control device. At the same time, he "feels the machine" much worse, and productivity is often reduced.

The second level is telemetric control: mining equipment is controlled by an operator located at a considerable distance, using cameras, sensors, etc. Telemetric control allows the operator to control equipment from a safe place, as well as receive more information about the condition and location of machines. A decrease in productivity can occur here too, however, the operator is removed from the danger source at a much greater distance than with the remote control.

At the third level, one operator regulates the activities of several units of equipment that move according to the algorithm laid down by the program. The operator controls the process, making adjustments if necessary.

The fourth, highest level is full automation, when the equipment works completely independently, without human participation. With full automation, autonomous systems take full control of ignition, gear shifting, steering, braking, material dumping, etc. Full automation allows to increase the productivity of mining machines, and the use of programs to control the machines allows the operator to "manage" their operation, monitor efficiency and intervene in case of problems.

Today, surface mining in developed countries with a shortage and high cost of human labor is at the intermediate stage of transition to full automation. In developing and third world countries where human labor costs are low, the need for mining automation remains low too.

The first attempts to automate mining equipment were made back in the 1960s. Komatsu tested an unmanned mining truck in 1990 [3], Caterpillar did the same in 1995 [1], but autonomous trucks were first used in an operating mine in 2007. The main manufacturers investing in unmanned mining trucks are Komatsu, Caterpillar, and Hitachi. The Komatsu and Caterpillar autonomous haulage systems (AHSs) have already been widely implemented in real production [3-5], the Hitachi system has successfully passed tests and will be put into operation in 2020 [6]. BelAZ, Liebherr, Volvo, Xiangtan Electric Manufacturing Corporation (XEMC) and KamAZ also develop their own AHSs.

A generally accepted definition of AHS does not yet exist, therefore in this paper AHS refers to a system that includes personnel, technological devices, infrastructure, and software and allows mining trucks to operate without drivers.

The following critical components of the AHS can be distinguished: 
- Unmanned mining trucks equipped with electronic devices;

- Software that generates control commands, as well as controls and tracks the movement and interaction of trucks;

- Communication network with wireless coverage in all areas;

- Dispatchers who managing trucks, software and communications.

The territory of the mine is geographically divided into the working areas for manned and unmanned vehicles. All vehicles entering the unmanned zone are equipped with satellite transceivers that provide tracking, security perimeter or exclusion zone. Trucks receive instructions from a remotely located control room over a communications network.

Loading machines (usually manned) have location sensors so that the trucks stand right under the bucket before loading. Trucks can unload themselves at crushing points, stockpiles or dumps. Dispatching personnel can instruct trucks over wireless networks (Wi-Fi or 4G/LTE). Object detection subsystems equipped with RADARs and/or LiDARs are programmed to stop the truck if an obstacle arises in its way.

Therefore, each autonomous mining truck should be equipped with 1) wireless communications; 2) sensors for navigation and obstacle detection; 3) on-board equipment for processing data from sensors; 4) a controller for steering and braking coordination; 5) a navigation system for location determining in real time; 6) software for local and general control [7].

At today's stage, this equipment is usually installed on an existing machine. It is technically possible to dispose almost any equipment of the operator, but each case needs to be considered separately: is it possible to implement digital control in the machine, are standard protocols supported, etc. The cost of modernization is often commensurate with the cost of a new piece of equipment. Therefore, it is preferable to assemble an autonomous machine at the factory.

Almost all new trucks from the aforementioned manufacturers with a payload of 300 tons and more are developed taking into account the possibility of retrofitting. In the future, machines originally designed as unmanned vehicles will be produced.

In 2016, Komatsu introduced the IAHV (Innovative Autonomous Haulage Vehicle) mining truck concept with a payload of 250 tons without a driver's cab. The machine has four wheels with all-wheel drive (all wheels have separate control, both in turn and in rotation) and the ability to move forward and backward at the same speed. All steered wheels will reduce the turning radius, and, as a result, reduce the required space for maneuvering. The same forward and reverse speeds will reduce the number of U-turns. All this will significantly reduce the time for placing for loading and dumping, as well as reduce the area of loading and dumping zones.

BelAZ conducts similar developments: it is planned to block off or even remove the driver's cab; this will allow loading the truck in all directions [3].

A key component of the AHS is the truck dispatching system, which manages the work of the loading-and-transport complex of the mine and short-term planning of its work. Each manufacturer uses a "native" dispatching system: Komatsu uses the Dispatch system from owned Modular Mining Systems [8], Caterpillar uses its own MineStar system [8], Hitachi uses the Wencomine system from owned Wenco International Mining Systems.

In the FrontRunner AHS by Komatsu, management is tightly centralized. The control center monitors each machine in the unmanned zone, assigns trucks to loading and dumping points, and paves routes for them. The system monitors any possible interactions between unmanned and manned machines.

In the Command for Hauling AHS by Caterpillar, the main control is concentrated in the truck. The control center issues instructions on the allocation of vehicles between loading and dumping points, but the trucks themselves route and track possible interactions with other equipment - unmanned or not. Therefore, the onboard equipment of Caterpillar un- 
manned trucks is somewhat more complicated; they are equipped with both LiDARs and RADARs, while Komatsu trucks have only RADARs and conventional laser rangefinders to control the edge of the road. Caterpillar trucks have more expensive computing power on board, but are less dependent on the control center, which allows to "unload" it and use a larger number of trucks.

Surface mining operations that have already implemented or plan to implement the autonomous haulage in the near future are shown in the table.

Table. Implementation of the autonomous haulage at operating surface mines.

\begin{tabular}{|c|c|c|c|c|}
\hline Year & Company & Mine & Location & Trucks \\
\hline 2007 & Codelco & $\begin{array}{l}\text { Gabriela Mistral } \\
\text { (copper ore) }\end{array}$ & $\begin{array}{c}\text { Chile, } \\
\text { Antofagasta }\end{array}$ & $\begin{array}{c}\text { Komatsu 930E }(290 \mathrm{t}) \\
-18 \text { units }\end{array}$ \\
\hline 2008 & Rio Tinto & $\begin{array}{l}\text { West Angelas } \\
\text { (iron ore) }\end{array}$ & $\begin{array}{l}\text { Australia, } \\
\text { Pilbara }\end{array}$ & $\begin{array}{c}\text { Komatsu 930E }(290 \mathrm{t}) \\
-15 \text { units } \\
\end{array}$ \\
\hline 2011 & BHP Billiton & $\begin{array}{l}\text { Navajo Mine } \\
(\text { coal })\end{array}$ & $\begin{array}{c}\text { USA, } \\
\text { New Mexico }\end{array}$ & $\begin{array}{c}\text { Caterpillar 793F (227 t) } \\
-3 \text { units (trial) }\end{array}$ \\
\hline 2012 & Rio Tinto & $\begin{array}{l}\text { Yandicoogina } \\
\text { (iron ore) }\end{array}$ & $\begin{array}{l}\text { Australia, } \\
\text { Pilbara }\end{array}$ & $\begin{array}{c}\text { Komatsu 930E (290 t) } \\
-22 \text { units }\end{array}$ \\
\hline 2012 & Rio Tinto & $\begin{array}{l}\text { Hope Downs } 4 \\
\text { (iron ore) }\end{array}$ & $\begin{array}{l}\text { Australia, } \\
\text { Pilbara }\end{array}$ & $\begin{array}{c}\text { Komatsu 930E (290 t) } \\
-19 \text { units }\end{array}$ \\
\hline 2012 & $\begin{array}{c}\text { Fortescue } \\
\text { Metals Group }\end{array}$ & $\begin{array}{l}\text { Solomon Hub } \\
\text { (iron ore) }\end{array}$ & $\begin{array}{l}\text { Australia, } \\
\text { Pilbara }\end{array}$ & $\begin{array}{c}\text { Caterpillar } 793 \mathrm{~F}(227 \mathrm{t}) \\
-64 \text { units }\end{array}$ \\
\hline 2013 & Rio Tinto & $\begin{array}{l}\text { Nammuldi } \\
\text { (iron ore) }\end{array}$ & $\begin{array}{l}\text { Australia, } \\
\text { Pilbara }\end{array}$ & $\begin{array}{c}\text { Komatsu 930E }(290 \mathrm{t}) \\
-30 \text { units }\end{array}$ \\
\hline 2014 & BHP Billiton & $\begin{array}{l}\text { Jimblebar } \\
\text { (iron ore) }\end{array}$ & $\begin{array}{l}\text { Australia, } \\
\text { Pilbara }\end{array}$ & $\begin{array}{c}\text { Caterpillar } 793 \mathrm{~F}(227 \mathrm{t}) \\
-50 \text { units }\end{array}$ \\
\hline 2017 & Rio Tinto & $\begin{array}{l}\text { Silvergrass } \\
\text { (iron ore) }\end{array}$ & $\begin{array}{l}\text { Australia, } \\
\text { Pilbara }\end{array}$ & $\begin{array}{c}\text { Komatsu 930E }(290 \mathrm{t}) \\
-10 \text { units }\end{array}$ \\
\hline 2017 & Stanwell & $\begin{array}{l}\text { Meandu } \\
\text { (coal) }\end{array}$ & $\begin{array}{l}\text { Australia, } \\
\text { Queensland }\end{array}$ & $\begin{array}{c}\text { Hitachi EH5000 (296 t) } \\
-3 \text { units (trial) }\end{array}$ \\
\hline 2018 & $\begin{array}{c}\text { Fortescue } \\
\text { Metals Group }\end{array}$ & $\begin{array}{l}\text { Christmas Creek } \\
\text { (iron ore) }\end{array}$ & $\begin{array}{l}\text { Australia, } \\
\text { Pilbara }\end{array}$ & $\begin{array}{c}\text { Caterpillar 789D }(181 \mathrm{t}) \\
-35 \text { units }\end{array}$ \\
\hline 2018 & Suncor Energy & $\begin{array}{l}\text { North Steepbank } \\
\text { (oil sands) }\end{array}$ & $\begin{array}{l}\text { Canada, } \\
\text { Alberta }\end{array}$ & $\begin{array}{c}\text { Komatsu 930E, 980E } \\
-20 \text { units }\end{array}$ \\
\hline 2018 & Barrick Gold & $\begin{array}{l}\text { South Arturo } \\
\text { (gold) }\end{array}$ & $\begin{array}{l}\text { USA, } \\
\text { Nevada }\end{array}$ & $\begin{array}{c}\text { Komatsu 930E }(290 \mathrm{t}) \\
-5 \text { units }\end{array}$ \\
\hline 2019 & $\begin{array}{c}\text { Fortescue } \\
\text { Metals Group }\end{array}$ & $\begin{array}{l}\text { Cloudbreak } \\
\text { (iron ore) }\end{array}$ & $\begin{array}{l}\text { Australia, } \\
\text { Pilbara }\end{array}$ & $\begin{array}{c}\text { Caterpillar 789D }(181 \mathrm{t}) \\
-38 \text { units }\end{array}$ \\
\hline 2019 & Vale S.A. & $\begin{array}{l}\text { Brucutu } \\
\text { (iron ore) }\end{array}$ & $\begin{array}{c}\text { Brazil, } \\
\text { Minas Gerais }\end{array}$ & $\begin{array}{c}\text { Caterpillar 793F }(227 \mathrm{t}) \\
-13 \text { units }\end{array}$ \\
\hline 2019 & Brønnøy Kalk AS & $\begin{array}{l}\text { Brønnøy Kalk } \\
\text { (limestone) }\end{array}$ & $\begin{array}{l}\text { Norway, } \\
\text { Velfjord }\end{array}$ & $\begin{array}{l}\text { Volvo FH16 }(75 \mathrm{t}) \\
-6 \text { units (trial) }\end{array}$ \\
\hline 2019 & $\begin{array}{c}\text { SUEK-Khakassia } \\
\text { LLC }\end{array}$ & $\begin{array}{l}\text { Chernogorsky Cut } \\
\text { (coal) }\end{array}$ & $\begin{array}{l}\text { Russia, } \\
\text { Khakassia }\end{array}$ & $\begin{array}{l}\text { BelAZ 7513R (130 t) } \\
-2 \text { units (trial) }\end{array}$ \\
\hline 2020 & $\begin{array}{c}\text { State Power } \\
\text { Investment Corp. }\end{array}$ & $\begin{array}{l}\text { South Coal Mine } \\
(\text { coal })\end{array}$ & $\begin{array}{c}\text { China, } \\
\text { Inner Mongolia }\end{array}$ & $\begin{array}{c}\text { XEMC SF31904 (108 t) } \\
-2 \text { units (trial) }\end{array}$ \\
\hline 2020 & Whitehaven Coal & $\begin{array}{l}\text { Maules Creek } \\
\text { (coal) }\end{array}$ & $\begin{array}{c}\text { Australia, } \\
\text { New South Wales }\end{array}$ & $\begin{array}{l}\text { Hitachi EH5000 (296 t) } \\
-6 \text { units }\end{array}$ \\
\hline 2020 & Ferrexpo & $\begin{array}{l}\text { Yeristovo Mine } \\
\text { (iron ore) }\end{array}$ & $\begin{array}{c}\text { Ukraine, } \\
\text { Poltava Region }\end{array}$ & $\begin{array}{c}\text { Caterpillar } 789 \mathrm{C}, 793 \mathrm{D} \\
-15 \text { units } \\
\end{array}$ \\
\hline 2020 & Rio Tinto & $\begin{array}{l}\text { Koodaideri } \\
\text { (iron ore) }\end{array}$ & $\begin{array}{l}\text { Australia, } \\
\text { Pilbara }\end{array}$ & $\begin{array}{c}\text { Caterpillar } 793 \mathrm{~F}(227 \mathrm{t}) \\
-20 \text { units }\end{array}$ \\
\hline
\end{tabular}

As can be seen from the table, most of the autonomous surface mines are concentrated in Pilbara, the region in Western Australia, that has a tough climate: it holds the world rec- 
ord for duration of heat above $100^{\circ} \mathrm{F}\left(37,8^{\circ} \mathrm{C}\right)-160$ days. Here, about 60000 people live in an area of $502000 \mathrm{~km}^{2}$, and 9000 of them are engaged in iron ore mining. The main problem of mining companies operating in Pilbara is the lack of qualified personnel. Even for a large salary (up to 20000 dollars for a two-week shift), few agree to work in constant stress and heat.

\section{Prospects for autonomous haulage in surface mining}

Rio Tinto mining company was the first to eliminate expensive labor as much as possible and remove a significant number of employees from poorly tolerated working conditions. Today, Rio Tinto uses about 120 unmanned mining trucks (mainly Komatsu) at its Pilbara mines; these trucks are remotely controlled by operators from the control center in Perth, $1200 \mathrm{~km}$ from the operation site. Over the year, the productivity of autonomous operations compared with conventional ones increased by $13 \%$. The use of unmanned trucks over time amounted to almost $90 \%$ ( $80 \%$ for conventional ones). In 2017 , each autonomous truck worked 700 hours longer than the manned one, and operating costs decreased by $15 \%$. In addition, in 2019, Rio Tinto automated the railways, through which ore is transported to seaports, which also positively affected the efficiency of work.

According to forecasts, the potential reduction in operating costs in autonomous surface mines may be $30 \%, 17 \%$ of which is the cost of maintenance (due to increased tire life and improved collection of data on the technical condition of machines). Also in [7] it was established that more even movement of unmanned mining trucks will reduce fuel consumption by $5-7 \%$, and tire wear by $7 \%$.

Fortescue Metals Group company, also operating in Pilbara, traditionally uses Caterpillar equipment and is currently the leader in terms of automation - the total number of unmanned trucks at its operations is approaching 140. By mid-2020, this number is planned to be increased to 175 , and the entire mining truck fleet of the company will be unmanned.

Brazilian Vale S.A. company expects that the introduction of autonomous haulage will reduce fuel consumption by more than $10 \%$, maintenance costs by $10 \%$, tire wear by $25 \%$. The service life of the equipment will increase by $15 \%$, which will reduce capital costs and harmful emissions into the atmosphere.

Russian mining operations have so far limited themselves to local projects for the remote control of equipment. This is only the first level of automation, although there are precedents for more advanced solutions. Point solutions do not make much sense; in order to obtain high performance, an autonomous section must be implemented immediately, with prepared infrastructure, if possible isolated from roads where ordinary trucks move. The technology has not yet been developed due to a number of economic and technical reasons, as well as features of state regulation.

However, this situation is gradually changing. Back in the early 2010s, VIST Group company, in partnership with BelAZ, began the development of the domestic AHS named "Intelligent Mine". However, the beginning of field tests of the system had to wait almost 10 years.

In August 2019, VIST Group began testing a domestic autonomous mining haulage system based on BelAZ 7513R mining trucks. Two trucks with a payload of 130 tons operated at the Chernogorsky Cut (SUEK-Khakassia LLC) with an EKG-8U shovel $\left(8 \mathrm{~m}^{3}\right.$ bucket). Unmanned vehicles moved along the selected section of the mine with a length of $1350 \mathrm{~m}$ and carried overburden. According to the plan, the operation of autonomous trucks was supposed to go into a round-the-clock mode, and this cycle could be repeated without the need for direct human participation in the process.

The simultaneous movement of two trucks at once in one section is the most technologically difficult part of the project. To implement the two-vehicle drive-through, spe- 
cial algorithms that allow choosing the optimal sequence of trucks were created. There was also an intersection with the public highway on the site, for the passage of which an algorithm for the automated control of barriers and traffic lights was implemented.

Tests were previously conducted, during which the truck was moving non-stop for 24 hours at the BelAZ proving site, having completed 500 technological cycles. The unmanned system consisted of a mining truck with a payload of 130 tons and a front loader.

The main expected effect of the use of autonomous technology is a reduction in repair costs, a change in mining parameters (width of the loading zone, roads, change in the bench angles).

Another project of VIST Group is the testing of an autonomous site in real production in Morocco. The test section with a length of more than $1 \mathrm{~km}$ included all the main areas in which mining trucks have to operate: parking, main and alternative routes, loading and dumping areas, and also a gas station. An unmanned Terex truck and a manned Caterpillar loader worked on the site. The control server was located in the control room, as well as the operator's workplace. To test the environment scanning systems, a number of artificial obstacles were made. During the tests, an unmanned truck transported more than 5000 tons of phosphates in an autonomous mode.

Despite all the advantages, the current experience in implementing autonomous haulage systems in mining indicates that various problems arise during their implementation.

1. The lack of qualified personnel for the operation of unmanned equipment. To solve the problem, it is necessary to develop a retraining program for personnel managing unmanned mining trucks. Critics of automation claim that its implementation will lead to a reduction in the number of jobs. They are objected that automation, on the contrary, leads to the creation of new jobs, as productivity and production volumes increase.

2 . The problem of equipment compatibility. New equipment, production systems or assemblies often cannot be combined during the modernization with the rest of the chain for technical reasons. A situation arises when the introduction of a separate innovation necessitates updating the main part of the entire production complex. Under established economic conditions, most operations cannot afford this. For example, Russia does not produce the equipment necessary for automation of mining equipment, components have to be purchased abroad, where there are also not so many such manufacturers.

3. The problem of "interoperability". As foreign experience shows, the main problem of introducing AHSs is the impossibility of combining automated equipment and humancontrolled equipment on one site. The main reason is the imperfection of the communications (mainly Wi-Fi). If the network is broken, and unmanned trucks lose contact with other trucks, then they simply stop operating. Operation resumes after a manual visual inspection, which takes time. In addition, the obstacle detection subsystems of unmanned trucks often operate falsely, taking road bumps or small pieces of rock for obstacles. To restart the truck, again, manual inspection is required.

Also, the exclusion of the "human factor" can cause situations that would most likely not have happened with manned transport. In particular, in March 2019, two unmanned trucks collided at the Jimblebar mine. The incident was explained by heavy rain, as a result of which trucks strayed from predetermined routes. A month earlier, at the Christmas Creek mine, a moving unmanned truck collided with a parked one. The claimed cause is a Wi-Fi communication system failure.

4. The rise in price of equipment by $20-30 \%$ due to modernization and a long payback period. Significant financial investments do not guarantee immediate benefits. Therefore, large companies prefer to use low-cost and low-level automation (remote control). In addition, any computerization entails a software vulnerability, a threat of hacking the system.

5. Resistance of employees. This is caused by the same "human factor": fear of innovation, conservatism, fear of losing a job or one's irreplaceability, fear of significantly increas- 
ing responsibility for actions. In such cases, company managers should conduct explanatory work with personnel, create a solid feeling of the inevitability of implementation among employees at all levels, and give the project implementation managers sufficient authority, since resistance sometimes arises even at the level of senior management.

All this leads to the fact that at the moment the autonomous haulage is not used at most surface mines of the world [1].

\section{Conclusion}

Despite the aforementioned problems, everything goes to the fact that autonomous haulage in mining will develop and spread around the world further. Experts believe that mining will become more autonomous, trucks will process all the data on their own. In the near future, technologies such as $5 \mathrm{G}$ to better cover the communication network, the use of unmanned aerial vehicles, long-range cameras or other autonomous ground vehicles for manual visual inspection will be introduced. All this will continue for probably the next 20-30 years.

Mining companies and manufacturers of mining equipment can take a lot from the experience of highway vehicle automation, which is increasingly popular in the world. Obviously, there are more vehicles on public roads than off-highway trucks in surface mines. Prices for automation kits will gradually decrease, and it will be possible to conduct operations in an environment in which there is no satellite communication. Already, the cost of individual components, such as LiDARs, has halved since they began to be used about 10 years ago. Solid state LiDARs, which are cheaper than rotational ones, are already being introduced in the automotive industry.

Particular attention should be paid to mining trucks without a driver's cab (like the aforementioned Komatsu IAHV). It is possible that in the long term (in 20-30 years) cabs will become an additional and expensive option for installation on a heavy-duty mining truck.

It can be confidently said that the future of the mining industry is related to automation, which, although it has its drawbacks, is nevertheless clearly more advanced than current technologies.

\section{References}

1. D. Schmidt, Coal Age, 119(11), 26 (2014)

2. C. Brown, Eng. Min. J., 213(1), 30 (2012)

3. S. Fiscor, Eng. Min. J., 219(11), 52 (2018)

4. J. Parreira, An interactive simulation model to compare an autonomous haulage truck system with a manually-operated system (The University of British Columbia, Montreal, 2013)

5. O. Golbasi, K. Dagdelen, 38th APCOM symposium, 2, 19-9 (2017)

6. Report 2 - Autonomous mining equipment (RFC, Ambrian, 2019)

7. C. Leonida, Eng. Min. J. 220(12), 36 (2019)

8. D. M. Dubinkin, Mining Equipment and Electromechanics, 6, 8 (2019) 